\title{
PENERAPAN MODEL PEMBELAJARAN CREATIVE PROBLEM SOL VING (CPS) TIPE TREFFINGER UNTUK MENINGKATKAN BERPIKIR KREATIF PADA POKOK BAHASAN LARUTAN PENYANGGA
}

\author{
Florensya Elisabeth Simanjuntak ${ }^{1} 1$, Erviyenni $^{2}$, Asmadi M. Noer ${ }^{3}$ \\ ${ }^{1,2,3}$ Universitas Riau, Jalan Bina Widya KM 12,5, Simpang Baru, Kec. Tampan, Kota Pekanbaru, \\ Riau 28293
}

\begin{abstract}
Abstrak - Penelitian ini bertujuan mengetahui apakah model pembelajaran Creative Problem Solving tipe Treffinger dapat meningkatkan berpikir kreatif peserta didik pada pokok bahasan larutan penyangga di SMAN 9 Pekanbaru. Penelitian ini menggunakan rancangan penelitian Design Randomized Control Group Pretest-Posttest dengan instrumen pengumpul data berupa soal essay dan angket penilaian sikap kreatif peserta didik. Sampel penelitian terdiri dari 2 kelas, yaitu kelas XI MIA 4 sebagai kelas eksperimen dan kelas XI MIA 6 sebagai kelas control yang telah diuji normalitas menggunakan uji Liliefors dan uji homogenitas menggunakan uji kesamaan dua rata-rata. Hipotesis penelitian diuji dengan menggunakan uji-t pihak kanan. Hasil penelitian menunjukkan bahwa penerapan model pembelajaran Creative Problem solving tipe Treffinger dapat meningkatkan berpikir kreatif peserta didik pada pokok bahasan larutan penyangga dengan $t_{\text {hitung }}=2,07>\mathrm{t}_{\text {tabel }}=1,67$ dengan $\alpha=0,05$.
\end{abstract}

Kata kunci: Creative Problem Solving, Treffinger, Berpikir kreatif, Larutan penyangga

\begin{abstract}
The purpose of this research was to determine whether the implementation Treffinger Type Creative Problem Solving learning model can improve students' creative thinking on the topic of buffer solution. The type of this research was experimental research with experiment Design Randomize Control Group Pretest-Posttest. The data were collected by using essay test and the questionnaire to assess the students' creative attitude. The research sample consisted two classes namely class of XI MIA 4 as experiment class and class of XI MA 6 as control class. The normality test using Liliefors test, homogeneity test using equality of two average test and hypothesis test using test- $t$ right side were employed. This study showed that the implementation of Creative Problem Solving learning model type Treffinger could improved the students' creative thinking with $t_{\text {count }}=2.07>t_{\text {table }}=1,67$ in the $\alpha=0,05$.
\end{abstract}

Keywords: Creative Problem Solving, Treffinger, Creative Thinking, Buffer Solution

\section{PENDAHULUAN}

Pesatnya perkembangan ilmu pengetahuan dan teknologi memberikan dampak yang begitu besar terhadap aspek kehidupan, salah satunya yaitu munculnya permasalahan hidup yang kompleks dan kompetitif. Untuk menghadapi tantangan ini, diperlukan Sumber Daya Manusia (SDM) yang berkualitas dan memiliki keahlian hidup yang baik untuk bersaing dan berkompetisi. Salah satu upaya untuk meningkatkan kualitas SDM adalah melalui pendidikan. Nugraha (2009) menyatakan bahwa peningkatan SDM dapat dilakukan dengan adanya pendidikan yang baik. Pendidikan adalah

\footnotetext{
${ }^{1}$ Corresponding author: Jurusan Kimia, Universitas Riau, Pekanbaru 28293, Indonesia. Email:

florensya.simanjuntak@student.unri.ac.id
} 
salah satu unsur yang penting untuk meningkatkan kualitas SDM karena dengan menempuh pendidikan seseorang dapat memperoleh pengetahuan, pengalaman, dan keterampilan melalui proses pembelajaran (Muhibbin, 2010). Mengajar dengan kreatif dapat mengembangkan kualitas pendidikan, membuat pembelajaran lebih bermakna dan membuka cara-cara yang lebih menyenangkan dalam mendekati kurikulum (Beetlestone, 2013).

Kurikulum 2013 menuntut peserta didik untuk berperan aktif dalam proses pembelajaran, karena pada kurikulum ini pembelajaran menitik beratkan pada peserta didik (students centered). Guru berperan sebagai fasilitator atau mediator dan perancang pembelajaran agar peserta didik aktif mencari pengetahuan baru (Sani, 2014). Minsed kurikulum 2013 adalah ingin menciptakan manusia Indonesia yang kreatif (Yani, 2014). Sebagai seorang pendidik, guru juga harus bisa membuat peserta didik menjadi pribadi yang kompeten, tidak sebatas membuat peserta didik tahu dan mengerti saja melainkan mampu membuat peserta didik menjadi pribadi yang kreatif. Hal ini dikarenakan perkembangan zaman yang menuntut individu untuk bersaing secara global, sehingga diperlukan kemampuan untuk menciptakan ide atau gagasan baru yang diperoleh dari kemampuan berpikir kreatif seseorang.

Sejauh ini kreativitas peserta didik belum mendapatkan perhatian dalam proses pembelajaran terutama pada mata pelajaran sains. Kreativitas peserta didik yang kurang diperhatikan dan diapreasiasi dalam pembelajaran menyebabkan peserta didik tidak mau bahkan takut untuk melakukan suatu hal yang baru. Padahal kreatif bukan hanya kemampuan untuk menghasilkan produk saja melainkan kemampuan menciptakan sebuah solusi yang tidak terpaku pada suatu jawaban benar pun dapat dikatakan kreatif. Hal ini selaras dengan pernyataan Bono (2007) bahwa kebutuhan untuk selalu memberikan jawaban yang benar di sekolah menghambat kemampuan berpikir kreatif peserta didik.

Sains merupakan ilmu pasti yang identik dengan rumus, misalnya pada pelajaran kimia yaitu materi larutan penyangga. Soal-soal yang diberikan menuntut peserta didik untuk dapat mengaplikasikan rumus, namun hal tersebut membuat peserta didik terpaku pada rumus dan jawaban yang diberikannya pun merupakan jawaban yang pasti. Akibatnya kemampuan berpikir kreatif peserta didik menjadi terbatas. Apabila diberikan permasalahan yang baru, peserta didik sulit untuk menemukan solusinya karena terbiasa dengan soal yang sifatnya tertutup.

Berdasarkan hasil wawancara dengan salah satu guru di SMAN 9 Pekanbaru diperoleh informasi bahwa kemampuan kimia peserta didik masih kurang. Kemampuan yang dimaksud adalah kemampuan komunikasi dan penalaran, dimana pada pokok bahasan larutan penyangga kurang dari 50\% peserta didik dalam satu kelas yang mampu memberikan pendapat dan menganalisa soal apabila sudah diberikan masalah yang berbeda. Hal ini diakibatkan karena kurangnya kemampuan berpikir kreatif peserta didik pada proses pembelajaran berlangsung dan kurangnya pembiasaan terhadap variasi soal.

Untuk menyelesaikan permasalahan di atas maka diperlukan model pembelajaran yang mampu meningkatkan berpikir kreatif peserta didik. Salah satu model pembelajaran yang dapat meningkatkan berpikir kreatif peserta didik yaitu model pembelajaran Treffinger. Model ini melibatkan dua ranah, yaitu kognitif dan afektif melalui tiga tahapan, yaitu Basic Tools yaitu tahap permasalahan dasar dan memberikan banyak gagasan, Practice with Process yaitu memusatkan perhatian peserta didik kepada masalah yang lebih kompleks dan memberikan gagasan yang berbeda dan Working with Real Problems yaitu peserta didik mengelola dirinya sendiri dengan mengaitkan tahap pertama dan kedua kedalam tantangan-tantangan dalam kehidupan (Aris Shoimin, 2014). 


\section{METODE}

Penelitian ini dilaksanakan di kelas XI MIA SMAN 9 Pekanbaru semester genap, tahun ajaran 2018/2019. Waktu pengambilan data dilakukan pada bulan Februari-Mei 2019. Sampel penelitian ini didapatkan setelah dilakukan uji normalitas Liliefors untuk mengetahui apakah data berdistribusi normal atau tidak. Kelas yang berdistribusi normal kemudian dilakukan uji homogenitas untuk mengetahui apakah kelompok sampel memiliki kemampuan yang sama. Kemudian dipilih dua kelas secara acak dengan cara diundi untuk dijadikan sampel. Kelas XI MIA 4 sebagai kelas eksperimen (dibelajrkan dengan model Treffinger) dan kelas XI MIA 6 sebagai kelas kontrol (tanpa model Treffinger). Desain penelitian yang dilakukan adalah Design Randomized Control Group Pretest-Posttest yang dapat dilihat pada Tabel 1.

Tabel 1. Desain Penelitian

\begin{tabular}{cccc}
\hline Kelas & Pretest & Perlakuan & Posttest \\
\hline Eksperimen & $\mathrm{T}_{\mathrm{O}}$ & $\mathrm{X}$ & $\mathrm{T}_{1}$ \\
\hline Kontrol & $\mathrm{T}_{\mathrm{O}}$ & - & $\mathrm{T}_{1}$ \\
\hline
\end{tabular}

Keterangan:

$\mathrm{T}_{\mathrm{O}} \quad$ : Nilai pretest kelas eksperimen dan kelas kontrol

$\mathrm{X} \quad$ : Perlakuan terhadap kelas eksperimen (model pembelajaran Creative Problem Solving tipe Treffinger)

$\mathrm{T}_{1} \quad$ : Nilai posttest kelas eksperimen dan kelas kontrol

(Mohammad Nasir, 2005)

Tahap analisis data pada penelitian ini dilakukan dengan tahap: (1) memberikan skor pada setiap soal tes essay berdasarkan rubrik penilaian indikator berpikir kreatif; (2) menghitung persentase penilaian sikap kreatif peserta didik; (3) menghitung perbedaan nilai LKPD dan evaluasi peserta didik kelas eksperimen dan kelas kontrol; dan (4) menghitung penilaian kinerja presentasi dan kinerja praktikum peserta didik.

\section{HASIL DAN PEMBAHASAN}

\section{Hasil}

\section{Uji Pra-Analisis}

Hasil analisis uji normalitas data data pra-analisis terlihat bahwa kedua sampel terdistribusi normal, pada sampel 1 diperoleh $\mathrm{L}_{\text {maks }}<\mathrm{L}_{\text {tabel yaitu }} 0,14<0,15$ dan sampel 2 diperoleh $\mathrm{L}_{\text {maks }}<\mathrm{L}_{\text {tabel }}$ yaitu $0,10<0,15$ dapat dilihat pada Tabel 2 sebagai berikut:

Tabel 2. Hasil Uji Normalitas Data Pra-Analisis

\begin{tabular}{ccccccc}
\hline Kelas & $\mathrm{N}$ & $\bar{x}$ & $\mathrm{~S}$ & $\mathrm{~L}_{\text {maks }}$ & $\mathrm{L}_{\text {tabel }}$ & Keterangan \\
\hline XI MIA 4 & 36 & $\mathbf{6 4 , 7 2}$ & 16,51 & 0,14 & 0,15 & Berdistribusi Normal \\
XI MIA 6 & 36 & $\mathbf{6 4 , 6 9}$ & $\mathbf{1 5 , 2 0}$ & 0,10 & 0,15 & Berdistribusi Normal \\
\hline
\end{tabular}

Keterangan:

$\mathrm{N}=$ Jumlah data pada sampel

$\bar{x}=$ Nilai rata-rata sampel

$$
\begin{aligned}
& \mathrm{S}=\text { Simpangan baku } \\
& \mathrm{L}=\text { Lambang statistik untuk menguji normalitas }
\end{aligned}
$$

Selanjutnya uji varians dilakukan sebagai syarat dari uji homogenitas, karena data yang diuji harus mempunyai varians yang sama. Data sampel memiliki varians yang sama, diperoleh $\mathrm{F}_{\text {hitung }} \leq \mathrm{F}_{\text {tabel }}$ yaitu $1,18 \leq 1,76$. Nilai thitung diperoleh 0,0078 dan nilai tabel untuk uji dua pihak pada $\alpha=0,05$ dengan $\mathrm{dk}=67$ adalah 2,00. Nilai thitung terletak antara $-\mathrm{t}_{\text {tabel }}$ dan $\mathrm{t}_{\text {tabel }}(-2,00<0,0078<2,00)$, artinya rata-rata kelompok sampel dapat dikatakan homogen. Hasil analisis uji homogenitas dapat dilihat pada Tabel 3. 
Tabel 3. Hasil Uji Homogenitas Data Pra-Analisis

\begin{tabular}{ccccccccc}
\hline Kelas & $\mathrm{N}$ & $\sum X$ & $\bar{x}$ & $\mathrm{~F}_{\text {hitung }}$ & $\mathrm{F}_{\text {tabel }}$ & $\mathrm{t}_{\text {hitung }}$ & $\mathrm{t}_{\text {tabel }}$ & Keterangan \\
\hline XI MIA 4 & 36 & 2330 & 64,72 & 1,18 & 1,76 & 0,0078 & 2,00 & Homogen \\
XI MIA 6 & 33 & 2135 & 64,70 & & & & &
\end{tabular}

\begin{tabular}{lll}
\hline Keterangan: & \\
$\mathrm{N}$ & $=$ Jumlah data pada sampel & $\bar{x}=$ Nilai rata-rata sampel \\
$\sum X$ & $=$ Jumlah nilai ulangan & $\mathrm{F}=$ Lambang statistik untuk menguji varians \\
$\mathrm{t}$ & $=$ Lambang statistik untuk menguji & kesamaan dua rata-rata
\end{tabular}

\section{Uji Hipotesis}

Uji normalitas dilakukan pada nilai akhir pretest-posttest sebelum dilakukan uji hipotesis. Hasil analisis uji normalitas dapat dilihat pada Tabel 4 sebagai berikut:

Tabel 4. Hasil Uji Normalitas Data Pretest-Posttest

\begin{tabular}{cccccccc}
\hline Data & Kelas & $\mathrm{N}$ & $\bar{x}$ & $\mathrm{~S}$ & $\mathrm{~L}_{\text {maks }}$ & $\mathrm{L}_{\text {tabel }}$ & Keterangan \\
\hline \multirow{2}{*}{ Pretest } & Eksperimen & 36 & 23,61 & 6,82 & 0,12 & 0,15 & \\
& Kontrol & 33 & 23,73 & 8,16 & 0,14 & 0,15 & \multirow{2}{*}{ Berdistribusi Normal } \\
\multirow{2}{*}{ Posttest } & Eksperimen & 36 & 82,17 & 9,78 & 0,13 & 0,15 & \\
& Kontrol & 33 & 77,27 & 9,38 & 0,10 & 0,15 & \\
\hline
\end{tabular}

Keterangan:

$\mathrm{S}=$ Simpangan baku

Uji hipotesis menggunakan pengujian statistik yaitu uji-t pihak kanan. Diperoleh $t_{\text {hitung }}>t_{\text {tabel }}$ yaitu 2,07>1,67. Hasil analisis uji hipotesis dapat dilihat pada Tabel 5 sebagai berikut:

Tabel 5. Hasil Uji Hipotesis

\begin{tabular}{ccccccccc}
\hline Kelas & $\mathrm{N}$ & $\sum X$ & $\bar{X}$ & $\sum_{X^{2}}$ & $\mathrm{~S}_{\text {gab }}$ & $\mathrm{t}_{\text {hitung }}$ & $\mathrm{t}_{\text {tabel }}$ & Keterangan \\
\hline Eksperimen & 36 & 2108,3 & 58,56 & 125759,61 & 10,05 & 2,07 & 1,67 & $\begin{array}{c}\text { Hipotesis } \\
\text { diterima }\end{array}$ \\
\hline Kontrol & 33 & 1766,68 & 53,53 & 99063,75 & &
\end{tabular}

Keterangan:

$\bar{X} \quad=$ Nilai rata-rata selisih posttest dan pretest

$\sum X^{2}=$ Jumlah nilai selisih posttest dan pretest dikuadratkan

$\mathrm{S}_{\mathrm{gab}} \quad=$ Nilai standar deviasi gabungan

\section{Peningkatan Berpikir Kreatif Peserta Didik}

Besarnya peningkatan berpikir kreatif peserta didik diketahui dari tes kemampuan berpikir kreatif, yaitu selisih nilai posttest dan pretest yang juga digunakan sebagai uji hipotesis. Penilaian soal pretest/posttest dilakukan dengan rubrik penilaian indikator berpikir kreatif untuk setiap soal pretest/posttest. Menurut Munandar (1999) indikator berpikir kreatif yang dapat diukur adalah keterampilan berpikir lancar (fluency), keterampilan berpikir luwes (flexibility), keterampilan berpikir luwes (originality) dan keterampilan memperinci (analyze).

Salah satu instrumen penilaian yang dapat mengukur keterampilan berpikir kreatif peserta didik adalah instrumen soal essay yang menuntut jawaban kretaif. Instrumen ini dilengkapi dengan rubrik penilaian yang sesuai dengan indikator berpikir kreatif. Indikator berpikir kreatif tersebut diuraikan menjadi beberapa sub indikator dalam bentuk kisi-kisi instrumen soal yang berupa tes (soal-soal essay) dan non-tes (rubrik penilaian berpikir kreatif). Kisi-kisi ini digunakan sebagai pedoman penskoran kemampuan berpikir kreatif (Marwiyah, 2015). Rumus yang digunakan untuk menghitung tes kemampuan berpikir kreatif yaitu:

$$
\text { Nilai }=\frac{\text { Jumlah Skor }}{\text { Skor Maksimum }} \times 100 \%
$$

Rata-rata nilai pretest/posttest kelas eksperimen dan kelas control disajikan pada Gambar 1. 


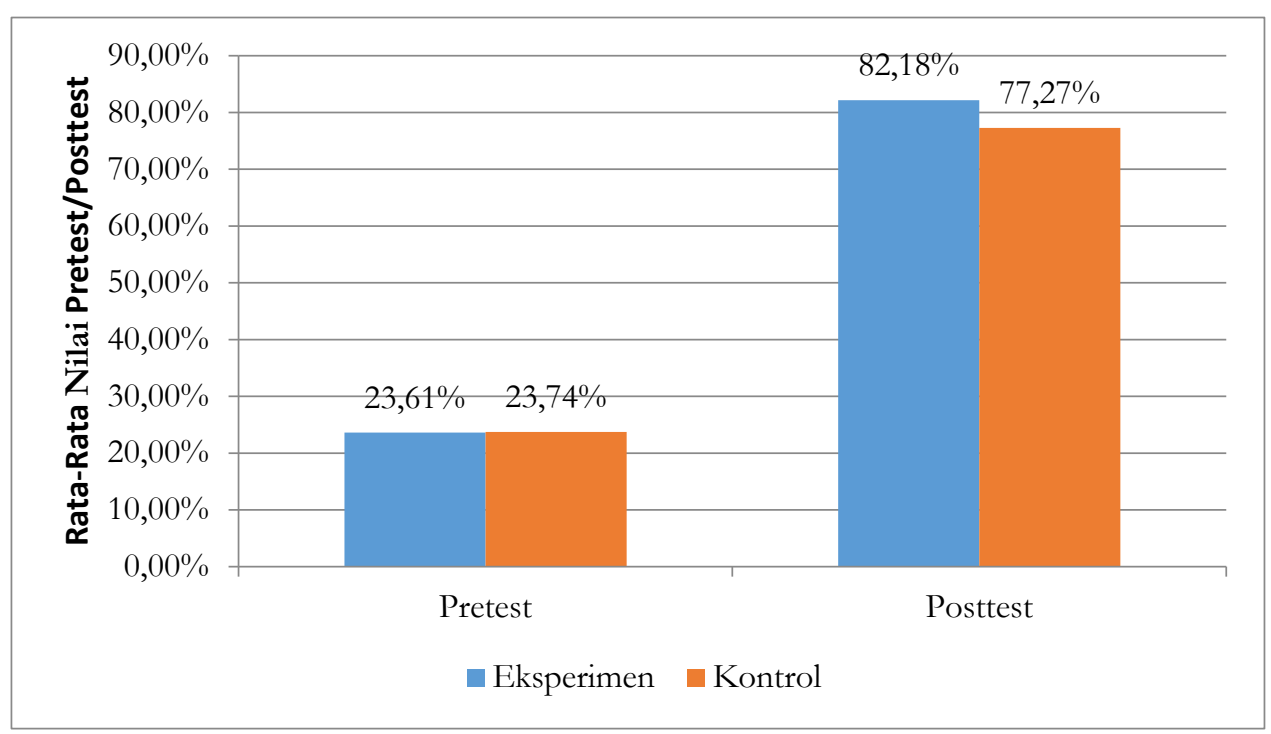

Gambar 1. Grafik Rata-Rata Nilai Pretest/Posttest

\section{Penilaian Sikap Kreatif Peserta Didik Kelas Eksperimen dan Kelas Kontrol}

Data penilaian sikap kreatif peserta didik dinilai melalui 6 sikap yakni rasa ingin tahu, imajinatif, orisinil dalam ungkapan gagasan, berani mengambil resiko, menghargai dan berani mengambil resiko (Sulistiarmi, dkk, 2016). Persentase penilaian sikap kreatif setiap pertemuan disajikan pada Tabel 6 dan Gambar 2

Tabel 6. Persentase Penilaian Sikap Kreatif Setiap Pertemuan

\begin{tabular}{cccccc}
\hline Kelas & Pertemuan 1 & Pertemuan 2 & Pertemuan 3 & Pertemuan 4 & Pertemuan 5 \\
\hline Eksperimen & 61,15 & 63,33 & 63 & 63,93 & 64,86 \\
\hline Kontrol & 52,52 & 53,28 & 55,15 & 57,62 & 57,02 \\
\hline
\end{tabular}

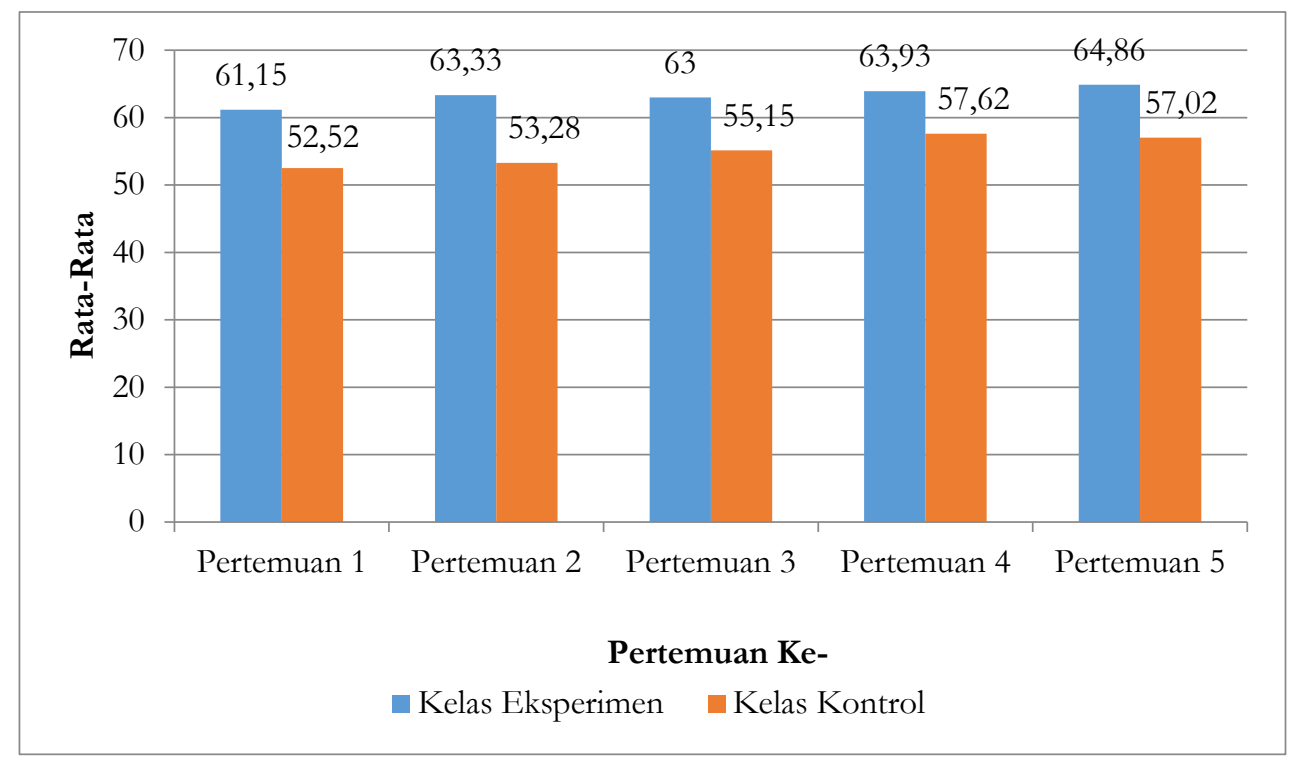

Gambar 2. Persenase Penilaian Sikap Kreatif Setiap Pertemuan 


\section{Pembahasan}

Uji normalitas dan homogenitas data pra-analisis bertujuan untuk mendapatkan sampel yang berdistribusi normal dan memiliki kemampuan yang sama. Dengan dilakukannya perhitungan uji normalitas dan uji homogenitas didapatkan kelas XI MIA 4 sebagai kelas eksperimen dan kelas XI MIA 6 sebagai kelas kontrol.

Uji hipotesis peningkatan berpikir kreatif peserta didik menunjukkan bahwa penerapan model pembelajaran CPS tipe Treffinger dapat memberikan hasil yang lebih baik daripada kelas kontrol. Hasil uji hipotesis menggunakan uji-t pihak kanan menghasilkan $t_{\text {hitung }}>t_{\text {tabel }}(2,07>1,67)$. Peserta didik kelas eksperimen yang yang dibelajrkan menggunakan model pembelajaran CPS tipe Treffinger memiliki kemampuan berpikir kreatif yang lebih tinggi dan memiliki sikap kreatif yang lebih baik dari kelas kontrol.

Peningkatan berpikir kreatif peserta didik ini disebabkan karena dengan penerapan model pembelajaran CPS tipe Treffinger dapat mempengaruhi kemampuan berpikir kreatif peserta didik yang dimilikinya. Model pembelajaran CPS tipe Treffinger menuntut semua peserta didik untuk aktif memberikan gagasannya dan terampil dalam memecahkan masalah yang dihadapinya. Model pembelajaran CPS tipe Treffinger juga melatih sikap kreatif peserta didik karena apabila seseorang dilatih kemampuan berpikir kreatifnya maka dia juga memiliki sikap kreatif (Sulistiarmi dkk, 2016). Peningkatan kemampuan berpikir kreatif peserta didik dinilai dari soal-soal Pretest-Posttest, LKPD dan evaluasi yang didalamnya terkandung indikator-indikator berpikir kreatif. Indikator berpikir kreatif tersebut yaitu keterampilan berpikir lancar (fluency), keterampilan berpikir luwes (flexibility), keterampilan berpikir orisinil (originality), dan keterampilan memperinci (analyze) (Utami Munandar, 1999). Rangkaian proses pembelajaran Treffinger dimulai dari Basic Tools, Practice with Process, Working with Real Problem membuat peserta didik terlibat aktif dalam proses pembelajaran dan memungkinkan peserta didik untuk menyelesaikan permasalahan-permasalahan yang ditemukannya (Shoimin, 2014).

Faktor yang dianggap mempengaruhi kemampuan berpikir kreatif peserta didik dalam proses pembelajaran adalah: (1) kesulitan saat menggunakan atau menafsirkan istilah, konsep dan prinsip: (2) peserta didik lupa dengan materi sebelumnya yang telah dipelajari yang berkaitan dengan materi yang sedang diajarkan: (3) peserta didik mengalami kesalahan procedural dalam mengerjakan soal tes karena salah mencermati perintah soal dan juga kesalahan tidak menjawab soal. Ketiga faktor tersebut menjadi penyebab umum peserta didik mengalami kesulitan dalam mengerjakan soal pretest-posttest, LKPD, dan evaluasi.

Hasil pennelian menunjukkan bahwa sikap kreatif peserta didik kelas eksperimen berbeda dengan kelas kontrol. Gambar 1 menunjukkan bahwa rata-rata sikap kreatif peserta didik kelas eksperimen lebih tinggi dari kelas kontrol. Hal ini disebabkan karena setiap tahapan model pembelajaran CPS tipe Treffinger menuntut peserta didik untuk berpikir kreatif dalam menyelesaikan permasalahan dan menimbulkan sikap kreatif yang baik. Sikap kreatif peserta didik dinilai melalui angket pengamatan selama proses pembelajaran berlangsung. Sikap yang diamati yaitu rasa ingin tahu, imajinatif, orisinil dalam ungkapan gagasan, berani mengambil resiko, menghargai dan mampu melihat masalah dari berbagai sudut pandang. Apabila seseorang mampu berpikir kreatif maka juga akan mempunyai sikap kreatif yang mendukung berpikir kreatif yang dimiliki seseorang. Contohnya pada indikator berpikir kreatif yaitu berpikir lancar, maka diperlukannya rasa ingin tahu yang tinggi agar peserta didik mampu menyelesaikan permasalahan yang dijumpainya.

\section{KESIMPULAN}

Berdasarkan hasil penelitian dan pembahasan yang telah diuraikan, maka dapat disimpulkan bahwa penerapan model pembelajaran CPS tipe Treffinger mampu meningkatkan berpikir kreatif peserta didik di SMAN 9 Pekanbaru pada materi larutan penyangga. 


\section{DAFTAR RUJUKAN}

Beetlestone, F. (Ed). (2013). Creative Learning. Strategi Pembelajaran untuk Melesatkan Kreativitas Siswa. Bandung. Penerbit Nusa Media.

Bono (Ed). (2007). Revolusi Berpikir. Bandung. PT Mizan Pustaka.

Marwiyah, S., Kamid., dan Risnita. (2015). Pengembangan Instrumen Penilaian Keterampilan Berpikir Kreatif pada Mata Pelajaran IPA Terpadu Materi Atom, Ion, dan Molekul SMP Islam Al Falah. EduSains, 4(1).

Muhibbin, S. (2010). Psikologi Penelitian dengan Pembelajaran Baru. Bandung. PT. Rosdakarya.

Munandar, U. (1999). Kreatifitas dan keberbakatan. Strategi menujudkan Potensi Kreatif dan Bakat. Jakarta. Gramedia Pustaka Utama.

Nazir, M. (2005). Metode Penelitian. Jakarta. Ghalia Indonesia.

Nugraha, D. (2009). Penerapan Model Pembelajaran Creative Problem Solving dalam Upaya Meningkatkan Kemampuan Berpikir Kreatif Siswa Pada Mata Pelajaran Teknologi dan Komunikasi. Skripsi Jurusan Ilmu Computer FPMIPA UPI. Bandung. Tidak Diterbitkan.

Sani, R. A. (2013). Pembelajaran Saintifik untuk Implementasi Kurikulum 2013. Jakarta. PT Bumi Aksara.

Shoimin, A. (2014). 68 Model Pembelajaran Inovatif dalam Kurikulum 2013. Yogyakarta. Ar-Ruzz Media.

Sulistiarmi, W., Wiyanto., dan Sunyoto E. (2016). Analisis Kemampuan Berpikir Kreatif Siswa Kelas XIIPA pada Mata Pelajaran Fisika SMA Negeri Se-Kota Pati. Unnes Physics Education Journal. Semarang. Jurusan Fisika UNS.

Yani, A. (2014). Minsed kurikukulum 2013. Bandung. Alfabeta CV. 